\title{
Tectonometamorphic evolution of collisional orogenic belts in the Korean Peninsula: Implications for East Asian tectonics
}

\author{
Moonsup Cho \\ School of Earth and Environmental Sciences, Seoul National University, Seoul, 151-747, KOREA \\ E-mail:moonsup@snu.ac.kr
}

The Korean Peninsula consists of three Precambrian massifs (Nangrim, Gyeonggi and Yeongnam massifs from north to south), bisected by two Phanerozoic fold-thrust belts (Imjingang and Ogcheon belts). Tectonometamorphic evolution of these terranes is of prime importance for understanding the continental growth of East Asia. In particular, the eastward extension of the Dabie-Sulu collisional belt between North and South China cratons, across the Korean Peninsula towards Japan, has been discussed by many workers but still contentious. In this study I review the PermoTriassic collisional orogeny recorded in the Korean Peninsula.

The Ogcheon fold-thrust belt consists of the Taebaeksan basin and the Ogcheon metamorphic belt, which are in fault contact. The Paleozoic formations in the Taebaeksan basin are well correlated with those of the North China craton. On the other hand, the Ogcheon metamorphic belt comprises Neoproterozoic (ca. $750 \mathrm{Ma}$ ) to Paleozoic meta-sedimentary and -volcanic sequences which may belong to the South China craton. Regional metamorphism has produced the Barrovian-type assemblage at peak metamorphic conditions estimated to be 4.2-9.4 kbar and $490-630^{\circ} \mathrm{C}$. This syn-tectonic metamorphism in association with the Ogcheon orogeny was dated at ca. $280 \mathrm{Ma}$. During the subsequent Indosinian (Songrim) orogeny at ca. 250-220 Ma, the Ogcheon metamorphic belt experienced the greenschist-facies metamorphism and was thrust over the Taebaeksan basin along brittle-ductile shear zones.
The Imjingang belt, commonly known as an extension of the Dabie-Sulu belt, consists primarily of Barrovian-type metapelites, calc-silicate rocks and garnet amphibolites. Biotite poikiloblasts of the metapelites initially grew between two contractional events (Dn-1 and Dn), and was subsequently overgrown during Dn by crack-filling mechanism. On the other hand, the growth of poikiloblastic garnet started after Dn-1, and predominated during Dn. The garnet porphyroblast partly replaced biotite at the postDn stage. Peak temperatures were estimated at $450-700^{\circ} \mathrm{C}$, and metamorphic pressures apparently increase from ca. $8 \mathrm{kbar}$ in the garnet zone to ca. $11 \mathrm{kbar}$ in the kyanite zone. The matrix of the kyanite-zone schist, however, records much lower pressure of 5-7 kbar, suggesting a clockwise P-T path. The timing for high-P peak metamorphism was dated at ca. $250 \mathrm{Ma}$, whereas relatively rapid cooling through ca. $500-300^{\circ} \mathrm{C}$ took place at 230-220 Ma. The latter was associated with $\mathrm{Dn}+1$ responsible for rapid exhumation along a ca. $20 \mathrm{~km}$-wide ductile shear zone. The clockwise P-T-t history is similar to that documented in not only the basement gneisses of the Gyeonggi massif but also high$\mathrm{P}$ schists in the Alps. It is thus likely that the whole peninsula, including Phanerozoic fold-thrust belts and Precambrian basement massif, has experienced a crust thickening during the Permo-Triassic orogeny, and that the Dabie-Sulu collisional belt continues towards the Korean Peninsula. 